\title{
Raloxifene reduced vertebral fractures in postmenopausal women
}

Ettinger B, Black DM, Mitlak BH, et al, for the Multiple Outcomes of Raloxifene Evaluation (MORE) Investigators. Reduction of vertebral fracture risk in postmenopausal women with osteoporosis treated with raloxifene. Results from a 3-year randomized clinical trial.JAMA 1999 Aug 18;282:637-45.

QUESTION: In postmenopausal women with osteoporosis, does raloxifene reduce the rate of vertebral and non-vertebral fractures?

\section{Design}

Randomised (allocation concealed*), blinded (patients, clinicians, and outcome assessors), * placebo controlled trial.

Setting

180 clinical centres in 25 countries.

\section{Participants}

7705 postmenopausal women (mean age $67 \mathrm{y}, 96 \%$ white) with osteoporosis. Exclusion criteria included other bone diseases, postmenopausal symptoms, abnormal uterine bleeding, history of breast or endometrial cancer or thromboembolic disorders, other cancers, treated endocrine disorders except type 2 diabetes or hypothyroidism, renal lithiasis, abnormal hepatic or renal function, untreated malabsorption, and consumption of $>4$ drinks of alcohol/d. Follow up was $89 \%$.

\section{Intervention}

Women received calcium, $500 \mathrm{mg} / \mathrm{d}$, and cholecalciferol, 400 to $600 \mathrm{IU} / \mathrm{d}$, and were allocated to raloxifene, $120 \mathrm{mg} / \mathrm{d}(\mathrm{n}=2572)$; raloxifene, $60 \mathrm{mg} / \mathrm{d}(\mathrm{n}=2557)$; or placebo $(n=2576)$ after stratification for previous vertebral fractures.

\section{Main outcome measure}

Confirmed new vertebral fractures.

\section{Main results}

Fewer women in the raloxifene groups had $\geq 1$ vertebral fracture than did women in the placebo group for all women and for subgroup analysis using previous fracture data (table). The groups did not differ for nonvertebral fractures $(9.3 \%$ for placebo $v 8.5 \%$ for raloxifene groups), but bone mineral density was higher in the raloxifene groups than in the placebo group $(p<0.001)$. Women in the raloxifene groups withdrew from the study more often because of adverse events and developed more thrombosis $(1 \% v 0.3 \%)$; breast cancer incidence was decreased.

\section{Conclusions}

Raloxifene prevented vertebral fractures, but not nonvertebral fractures in postmenopausal women with osteoporosis. Results were more dramatic for women with previous fractures.

*See glossary.
Source of funding: Eli Lilly and Company.

For correspondence: Dr B Ettinger, Division of Research, Kaiser Permanente Medical Care Program, 3505

Broadway, 13th Floor, Oakland, $C A$ 94611-5400, USA

Fax +1510450 2097 $\geq 1$ vertebral fracture with raloxifene $v$ placebo in postmenopausal osteoporosis at 3 years $†$

\begin{tabular}{lccccc} 
Women & $\begin{array}{l}\text { Raloxifene } \\
\text { dose }\end{array}$ & Raloxifene & Placebo & RRR (95\%) & NNT \\
\cline { 2 - 6 } All & $60 \mathrm{mg} / \mathrm{d}$ & $6.6 \%$ & $10.1 \%$ & $35 \%(21$ to 47$)$ & $29(20$ to 52$)$ \\
\cline { 2 - 6 } & $120 \mathrm{mg} / \mathrm{d}$ & $5.4 \%$ & $10.1 \%$ & $46 \%(33$ to 56$)$ & $22(17 \mathrm{to} 33)$ \\
\hline With previous fractures & $60 \mathrm{mg} / \mathrm{d}$ & $14.7 \%$ & $21.2 \%$ & $35 \%(19$ to 48$)$ & $16(10$ to 38$)$ \\
\hline With no previous fractures & $120 \mathrm{mg} / \mathrm{d}$ & $10.7 \%$ & $21.2 \%$ & $53 \%(40$ to 63$)$ & $10(7$ to 15$)$ \\
\hline
\end{tabular}

†Abbreviations defined in glossary; RRR, NNT, and $\mathrm{Cl}$ calculated from data in article.

1 Lindsay R, Tohme JF. Obstet Gynecol 1990;76:290-5.

2 Ross PD, Davis JW, Epstein RS, et al. Ann Intern Med 1991;114:919-23.

3 Black DM, Cummings SR, Karpf DB, et al. Lancet 1996;348:1535-41.

4 Cummings SR, Black DM, Thompson DE, et al.JAMA 1998;80:2077-82. 